\title{
Does the Government Drive Chinese Banking Performance - An Analysis of the Chinese Banking System
}

\author{
Greg Moore \\ Park University - Parkville Campus \\ Ohaness Paskelian \\ University of Houston Downtown \\ Stephen Bell \\ Park University - Parkville Campus \\ Julia Creek
Park University - Parkville Campus
}

We evaluate the Chinese government, foreign investors and private investors' financial impact upon Chinese banking performance. The paper focuses on major banks within China and evaluates the relationship between the ownership structure and the overall financial performance of the Chinese banks. Our findings span the period of 2001-2016 and show a very strong inverse relationship between bank performance measures in high government ownership Chinese banks. Furthermore, we find positive relationship between private and foreign ownership levels and Chinese bank performance. We conclude that Chinese government ownership's primary motive is not optimal financial performance, but other non-financial motives.

Keywords: Corporate Governance, Ownership Structure, Performance, Chinese Banking

\section{INTRODUCTION}

China's emergence as a global economy is in part due to its banking system. Starting in the late 1970s and early 1980s, the Chinese government started ceding its tight control on the banking system and gradually allowing for the expansion and measured privatization of Chinese banks (Garcia-Herrero, Gavila, and Santabarbara, 2009). The Chinese government allowed for new banks to open, and also gave approval to private and foreign investors to acquire shares in those new banks. In addition, the government reformed the regulations related to interest rates on deposit accounts and lifted the maximum ceiling on lending rates. All these regulatory changes were done in order to modernize the Chinese banking system and make it more competitive with global financial institutions.

The process of reforming the banking system in China created a mix of ownership structure. The Chinese government is still the largest and exclusive shareholder in the Big Four banks, and also has 
substantial ownership stake in many other banks. In addition, many local and municipal authorities have ownership stakes in the Chinese banking system. In addition to government related entities, private investors and foreign investors are part of this ownership structure as well. Other than this mix of shareholders, Chinese banks are also subject to the influence of other stakeholders such as lenders, depositors, regulators, and bank managers and supervisors, thus creating a very complex corporate governance structure (Cousin, 2007). Wang and Huang (2004) argue that the Chinese government will not let its controlling stake in the banking system decline, and will not let banks fail during a crisis because the banking system plays such a vital role in economic growth and development.

In this research paper, we investigate the relationship between corporate governance and ownership structure on the efficiency and performance of Chinese Banks. The study covers the period from 2001 to 2016, during which the reverberations of the 2007-2008 financial crisis had some devastating effects on the banking system worldwide. We explore the determinants of bank performance by examining the quality of assets and profitability of Chinese banks. In particular, we study whether the presence of the Chinese government as a large shareholder within some banks significantly impacted performance during the financial crisis.

This research contributes to and extends the existing literature on corporate governance and banking performance. Furthermore, this research is one of the few research papers that studies the impact of the worldwide financial crisis of 2007-2008 on the Chinese banking system, and provides answers on whether the bank governance system provided a shield from the effects of the financial crisis.

\section{THE STRUCTURE OF BANKING INSTITUTIONS IN CHINA}

From the Communist Chinese revolution in 1949 to 1978, the People's Bank of China (PBOC) was the sole banking entity in the country. The PBOC handled both commercial banking and central banking functions for China during this time period. Increased demand for banking services led the Chinese government to create four additional banks, which are known as The Big Four; The Agricultural Bank of China, Bank of China, Industrial and Commercial Bank of China and China Construction Bank. The Big Four banks were mainly commercial banks while the PBOC was left to handle the nation's monetary policy exclusively. By the end of the $20^{\text {th }}$ century, at the cusp of Chinese economic expansion, the Chinese government felt the need to have more banks with diverse ownership structures in order to help with the country's growing demand for banking services. In addition, the Chinese government created specialized banks, known as Policy Banks, in order to concentrate on lending in particular industry sectors that seemed to have high priority (Hsu, 2016).

The banking system in China has evolved and currently contains a mixture of banks with different types of ownership concentrations with the Big Four banks being completely owned by the government. There are also mixed-ownership banks where the government has varying degrees of ownership but other local shareholders are also present. In addition, there are banks which have varying degrees of foreign ownership (Lin and Zhang, 2009).

\section{LITERATURE REVIEW}

In a seminal paper, Jensen and Meckling (1976) explore the drivers of value-maximization in firms. They argue that ownership plays an important role in aligning managers' interests with the shareholders, thus agency costs can be reduced if managers have ownership stakes within the company. In similar research, Alchian (1965) argues that government owned firms do not exercise market discipline upon themselves or their employees. Therefore, the majority of those firms go bankrupt or continually receive subsidies from their governments in order to remain in business. Alchian (1965) also noted that clearly defined property rights and private ownership are definitive precursors for reduction of agency costs.

There is a large amount of research examining the impact of ownership structure on bank performance and profitability. In an influential paper, La Porta, Lopez-de-Silanes, and Shleifer (2002), studied the impact and effects of government ownership on banking system efficiency and profitability 
around the world. They found that in countries with poor property rights, and unsophisticated and outdated financial systems, there was generally a higher percentage of governmental bank ownership. They also noticed that in many countries with relatively higher government banking ownership, efficiency of operations and profitability was not the highest priority.

Berger, De Young, Genay and Udell, (2000) argue that foreign-owned banks have a distinct advantage over local banks because of more sophisticated managerial skills and more experienced personnel. In addition, foreign-owned banks have the ability to provide better training and employee development than local banks. They also provide evidence that even if partially owned, a foreign bank is more efficient than local banks with no foreign ownership.

Altunbas et al. (2001) does not find any significant evidence of superiority for privately owned banks over government owned banks in Germany. However, Altunbas, et al. (2001) do note the cost efficiency of privately owned banks over government owned banks. Similarly, Micco et al. (2007) examined several European banks and did not find any significant difference in the ROA between private banks and government owned banks. Alternatively, Sapienza (2004) found that government owned banks in Italy charged less interest than private banks, thus they tended to have lower NIM than private banks. Berger et al. (2005) found similar results among Argentinian banks. The long-term profitability measures of government banks in Argentina tended to be lower than privately owned banks.

In the past few years, there have been some studies about ownership structure and bank performance in China. Kumbhakar and Wang (2005) studied the performance and efficiency of Chinese banks under different ownership structures. They found some evidence that the Big Four banks were less efficient than other mixed-ownership banks. In addition, Kumbhakar and Wang (2005) also investigated the impact of different 1990s era Chinese regulatory changes on bank efficiency and profitability. Kumbhakar and Wang (2005) concluded that those regulatory changes did not have any significant impact on the efficiency of the banking system. Lin and Zhang (2009) investigated the impact of ownership structure on bank performance in China over the period 1997-2004. They found no significant variations in performance among different types of banks in China, although they noticed state owned banks efficiency and asset quality were lower compared to non-state owned banks. Similarly, Jiang, Yao, and Zhang (2009) studied the Chinese banking system from 1995-2005 using the technical efficiency analysis method. Their results suggest that in general, government ownership had a negative impact on banking performance. They also found evidence that infusion of foreign ownership provided improvements to Chinese bank technical efficiency and performance.

\section{HYPOTHESIS AND METHODOLOGY}

Bonin, Hasan, and Wachtel (2005a, b) assert that for the majority of the banks worldwide, on average, bank efficiency and performance improves with greater foreign ownership. Furthermore, banks with government ownership have always lagged in their performance when compared to foreign-owned banks. Based on the literature, we propose the following hypotheses:

H1: In China, foreign ownership positively impacts banking performance and profitability.

H2: In China, government ownership negatively impacts banking performance and profitability.

Furthermore, following Berger et al. (2000) and Jensen and Meckling (1976), we also hypothesize the following:

H3: In China, private ownership positively impacts banking performance and profitability.

\section{DATA AND DESCRIPTIVE ANALYSIS}

The sample of banks used in this research span was from 2001 to 2016. The data was collected from two sources, the CSMAR and Bankscope databases. The sample contains 42 banks including the Big Four 
and Policy banks, and other banks with varying degrees of ownership concentrations. In order to have a sample of banks with complete data covering the entirety of the study period, we eliminated those banks with missing or incomplete data. Nevertheless, our sample accounts for the majority of the Chinese banks, and accounts for more than $91 \%$ of the total assets in the Chinese banking system.

TABLE 1

VARIABLES AND DEFINITIONS

\begin{tabular}{ll}
\hline Profitability Variables & \\
ROA - Return on Assets & Net income divided by total assets \\
ROE - Return on Equity & Net income divided by shareholder's equity \\
NIM - Net Interest Margin Banking & Net interest income divided by total assets \\
Factors & \\
SIZE - Bank Size & Natural log of total assets. \\
CAP - Capitalization & Total equity divided by total assets \\
ITL - Impaired Loans to Total Loans & Impaired loans to total loans ratio \\
LTA - Loan to Asset & Total loans divided by total assets \\
DTA - Deposit to Asset & Total deposits divided by total assets \\
LLPA - Loan Loss Provisions to Asset & Total loan loss provisions divided by total assets \\
Ownership Variables & \\
BIG - BIG Four & Dummy variable for The Big Four Government owned \\
& Chinese banks \\
GOV - Government Ownership & Percentage of shares owned by the Chinese government \\
IND - Independent Ownership & Percentage of shares owned by Chinese non-government \\
& investors \\
FOR - Foreign Ownership & Percentage of shares owned by Foreign investors \\
\hline
\end{tabular}

This table provides the definitions of the variables used in this paper and how those variables are calculated.

We use three profitability measures specific for the banking industry. The ROA is the ratio of net income to total assets, which measures a bank's ability to use its resources to generate profit. The ROE is the ratio of net income to shareholder equity, and measures the bank's ability to generate profit using shareholder provided capital. Finally, the NIM (net interest margin) is the net interest income divided by total assets. Net interest income is the interest earned on loans minus the interest paid on deposits. Raluca (2013), review of the banking profitability literature shows that these three variables are widely used in banking literature as profitability measures for banks. 
TABLE 2

DESCRIPTIVE STATISTICS

\begin{tabular}{lllll}
\hline & Mean & $\begin{array}{l}\text { Standard } \\
\text { Deviation }\end{array}$ & Maximum & Minimum \\
\hline ROA & 0.67 & 0.42 & 1.48 & -0.12 \\
ROE & 19.35 & 8.52 & 88.41 & -183.47 \\
ITL & 5.37 & 6.81 & 34.21 & 0.69 \\
SIZE & 5.68 & 0.54 & 7.15 & 2.58 \\
CAP & 0.04 & 0.03 & 0.14 & 0.01 \\
NIM & 2.14 & 0.96 & 4.17 & 0.68 \\
LTA & 0.49 & 0.21 & 0.97 & 0.01 \\
DTA & 0.81 & 0.25 & 0.98 & 0.01 \\
LLPA & 0.34 & 0.21 & 0.87 & 0.04 \\
GOV & 0.57 & 0.15 & 0.82 & 0.34 \\
IND & 0.23 & 0.47 & 0.67 & 0.02 \\
FOR & 0.11 & 0.56 & 0.41 & 0.01 \\
\hline
\end{tabular}

This table provides summary statistics for the sample. The dataset comprises 42 Chinese banks covering the period from 2001 to 2016. The descriptive statistics include: the return on assets (ROA), the return on equity (ROE), the ratio of impaired loans to total loans (ITL), the size of the bank measured as the natural log of total assets (SIZE), the bank capitalization (CAP), the net interest margin (NIM), the loan to asset ratio (LTA), the deposit to asset ratio (DTA), the total loan loss provisions (LLTA), the percentage of shares owned by the government (GOV), the percentage of shares owned by independent shareholders (IND), and the percentage of shares owned by foreigners (FOR).

The descriptive statistics for the sample are contained in Table 2 including the mean, standard deviation, minimum and maximum values of all the different variables used in the study. The return on assets (ROA) has a mean of 0.67 , with standard deviation of 0.42 which is quite large, and varies between -0.12 to 1.48 . The ROA values seem to be quite dispersed, and that is expected for Chinese banks. The return on equity (ROE) has a mean value of 19.35, standard deviation of 8.52 and ranges from -183.47 to 88.41. The net interest margin (NIM) has a mean value of 2.14, standard deviation of 0.96 and ranges from 0.68 to 4.17 . The government ownership variable (GOV) has a mean of 0.57 , a standard deviation of 0.15 and ranges from 0.34 to 0.82 , which shows strong presence of the Chinese government in the banking sector. The independent ownership variable (IND) has a mean of 0.23 , a standard deviation of 0.47 and ranges from 0.02 to 0.67 . The foreign ownership variable (FOR) has a mean value of 0.11 , a standard deviation of 0.56 and ranges from 0.01 to 0.41 . The size variable (SIZE) has a mean value of 5.68, a standard deviation of 0.54 and ranges from 2.58 to 7.15 . A first look at this variable suggest that Chinese banks are predominantly large banks, which is a realistic assumption in our sample since we include the Big Four in our banking sample. The capitalization variable (CAP) has a mean value of 0.04, a standard deviation of 0.03 and ranges from 0.01 to 0.14 . From the values of the capitalization variable, we confirm that our sample contains large banks since the equity over total assets ratio is rather small. The impaired loans to total loans ratio (ITL) has a mean value of 5.37, and a rather large standard deviation of 6.81 and ranges from 0.69 to 34.21 . The variation of the ITL variable is striking because it shows that in our sample, some banks have rather large proportions of bad loans. The loans to total assets ratio (LTA) has a mean value 0.49 , a standard deviation of 0.21 and ranges from 0.01 to 0.97 . This variable also provides rather surprising information since the maximum value is 0.97 , which suggests that some banks in the sample have made loans out of almost all of their assets. Similarly the deposits over total assets variable (DTA) has similar characteristics; its mean value is 0.81 , the standard deviation is 0.25 and ranges from 0.01 to 0.98 . Finally, the loan loss provisions to total asset variable (LLPA) has a mean value of 0.34 , a standard deviation of 0.21 and ranges from 0.01 to 0.87 . 
TABLE 3

\section{CORRELATIONS}

\begin{tabular}{llll}
\hline & $\begin{array}{l}\text { Government Ownership } \\
(\mathrm{GOV})\end{array}$ & $\begin{array}{l}\text { Independent Ownership } \\
(\mathrm{IND})\end{array}$ & $\begin{array}{l}\text { Foreign } \\
\text { Ownership (FOR) }\end{array}$ \\
\hline ROA & $-0.741^{* * *}$ & $0.271^{*}$ & $0.384^{* *}$ \\
ROE & $-0.125^{*}$ & 0.187 & $0.218^{*}$ \\
NIM & $-0.428^{*}$ & $0.384^{*}$ & $0.628^{* *}$ \\
ITL & $0.683^{* * *}$ & $-0.182^{*}$ & $-0.483^{* *}$ \\
SIZE & $0.942^{* * *}$ & $-0.129^{*}$ & $-0.281^{* *}$ \\
CAP & 0.178 & 0.391 & 0.308 \\
LTA & 0.421 & 0.247 & 0.241 \\
DTA & 0.584 & 0.318 & 0.178 \\
LLPA & 0.547 & 0.383 & 0.125 \\
\hline
\end{tabular}

This table provides data on the correlations between ownership variables and profitability measures. The dataset comprises 42 Chinese banks covering the period from 2001 to 2016.

Table 3 contains the correlation coefficients between ownership variables and financial statement variables. The striking result from the correlation analysis shows that all three profitability variables are negatively and significantly correlated to government ownership. The impaired loans to total loans ratio and bank size is significantly and positively correlated to government ownership, which suggest that government ownership does not translate into profitability and results in more bad loans, but bank size can increase with the government ownership. The ROA is significantly and positively correlated to the independent ownership and foreign ownership variables. The NIM variable is also significantly and positively correlated to the independent ownership and foreign ownership variables. The ROE is only significantly and positively correlated to the foreign ownership variable. Thus, from the correlations, we can assert that independent ownership and foreign ownership have a positive impact on Chinese bank profitability. Bank size is positively and significantly correlated to the government ownership variable, while it is significantly and negatively related to the both independent ownership and foreign ownership variables. Bank size tended to be larger for banks with large government ownerships, which is a result found in the banking literature for most of emerging market countries, where government banks tend to have larger sizes and employ more employees than non-government banks Raluca (2013). Finally, the impaired loans to total loans variable is positively and significantly correlated to the government ownership variable, while it is significantly and negatively related to the both independent ownership and foreign ownership variables, which also suggests that government ownership has a negative impact on bank performance by permitting the making of relatively more bad loans. The other variable correlation values were not significant.

\section{REGRESSION ANALYSIS RESULTS}

We investigate the determinants of bank profitability using different control variables, bank specific and ownership related, using ordinary least squares (OLS) regressions. We use three different specifications for modeling profitability factors. The dependent variables chosen are the ROA, ROE and NIM. The independent variables are banking related variables and ownership proportions. 
TABLE 4

OLS REGRESSIONS OF PROFITABILITY OF CHINESE BANKS - ROA

\begin{tabular}{llll}
\hline & ROA & ROA & ROA \\
\hline C & 0.048 & $0.817^{* *}$ & 0.521 \\
SIZE & $0.754^{* * *}$ & & $0.617^{* *}$ \\
CAP & $0.347^{* *}$ & & $0.214^{*}$ \\
ITL & $-1.284^{* * *}$ & & $-0.987^{* *}$ \\
LTA & $0.574^{*}$ & & 0.247 \\
DTA & $0.687^{* *}$ & & 0.158 \\
LLPA & $-0.471^{*}$ & $-0.157^{*}$ & 0.641 \\
BIG & & $-0.782^{* * *}$ & $-0.172^{* *}$ \\
GOV & & $0.028^{*}$ & $-0.628^{* *}$ \\
IND & & $0.239^{* * *}$ & 0.064 \\
FOR & & $0.047^{*}$ \\
\hline
\end{tabular}

This table provides OLS regression results of the determinants of profitability of Chinese banks. Using ROA as the dependent variable, three different specifications are used, the first using only bank specific financial statement variables as independent variables, the second using ownership concentration variables only as independent variables, and the third using both ownership concentrations and financial statement variables.

Table 4 provides the determinants of ROA for Chinese banks. The results demonstrate interesting relationships between the financial statement variables, ownership variables and the profitability measures. In the first specification, we model the determinants of the ROA using only financial statement variables. The results suggest that bank size, capitalization, the deposits over assets ratio and the loans over assets ratio all have positive and significant impact on the ROA. In addition, the loan to assets ratio and the loan loss provisions to asset ratio have significant and negative impact on the ROA. The second specification models ROA using only ownership related variables. We notice that the Big Four banks and banks with high government ownership, tend to have lower ROAs, while the independent ownership and foreign ownership increases the ROA of Chinese banks. Finally, the last specification where we include both financial statement and ownership variables as independent variables, we find similar results. Although, in the last specification, being big four or having large government ownership results in more significant impact on ROA than in the first two specifications.

TABLE 5

OLS REGRESSIONS OF PROFITABILITY OF CHINESE BANKS - ROE

\begin{tabular}{llll}
\hline & ROE & ROE & ROE \\
\hline C & 0.018 & 0.0481 & 0.0328 \\
SIZE & $0.421^{* *}$ & & $0.184^{* *}$ \\
CAP & $0.029^{*}$ & & $0.018^{*}$ \\
ITL & $-0.478^{*}$ & & -0.821 \\
LTA & 0.037 & & 0.158 \\
DTA & 0.1872 & & 0.369 \\
LLPA & -0.318 & $-0.038^{*}$ & 0.814 \\
BIG & & $-0.018^{*}$ & $-0.182^{*}$ \\
GOV & & 0.0274 & $-0.018^{*}$ \\
IND & & 0.0371 & 0.017 \\
FOR & & 0.005 \\
\hline
\end{tabular}

$*, * *$ and $* * *$ are significant at $10 \%, 5 \%$ and $1 \%$ respectively. 
This table provides OLS regression results of the determinants of profitability of Chinese banks. Using ROE as the dependent variable, three different specifications are used, the first using only bank specific financial statement variables as independent variables, the second using ownership concentration variables only as independent variables, and the third using both ownership concentrations and financial statement variables.

In Table 5, we examine determinants of Chinese bank ROE. Our analysis is similar to the procedure conducted previously on bank ROA. We use financial statement variables, ownership variables and profitability measures to perform the analysis. In the first specification, we model the determinants of the ROE using only financial statement variables. The results suggest that bank size and capitalization are the only variables that positively and significantly affect ROE. The second specification models ROE using only ownership related variables. Our results show that ROE is negatively impacted by the government ownership variable and whether the bank was one of the Big Four (also negative impact). Finally, the last specification includes both financial statement and ownership variables as independent variables. The results were similar to the other specifications in that ROE was affected positively by bank size and capitalization. As with the other specifications, being a Big Four bank or having relatively large government ownership negatively affects ROE.

TABLE 6

\section{OLS REGRESSIONS OF PROFITABILITY OF CHINESE BANKS - NIM}

\begin{tabular}{llll}
\hline & NIM & NIM & NIM \\
\hline C & $0.157^{*}$ & 0.053 & 0.041 \\
SIZE & $0.756^{* *}$ & & $0.138^{* *}$ \\
CAP & $0.279^{* *}$ & & $0.039^{*}$ \\
ITL & $-0.028^{*}$ & & $-0.182^{*}$ \\
LTA & 0.183 & & -0.715 \\
DTA & 1.391 & & 1.852 \\
LLPA & 1.841 & $-0.158^{* *}$ & 0.981 \\
BIG & & $-0.214^{* * *}$ & $-0.281^{* *}$ \\
GOV & $0.027^{* *}$ & $-0.182^{* *}$ \\
IND & & $0.018^{* *}$ & $0.071^{*}$ \\
FOR & & $0.028^{*}$ \\
\hline and $* * *$ are significant at $10 \%, 5 \%$ and $1 \%$ respectively. &
\end{tabular}

This table provides OLS regression results of the determinants of profitability of Chinese banks. Using NIM as the dependent variable, three different specifications are used, the first using only bank specific financial statement variables as independent variables, the second using ownership concentration variables only as independent variables, and the third using both ownership concentrations and financial statement variables.

In Table 6, we examine determinants of the NIM in Chinese banks. We conduct analysis similar to the specifications applied previously to ROA and ROE. We use financial statement variables, ownership variables and the profitability measures as independent variables. In the first specification, we model the determinants of the NIM using only financial statement variables. The results suggest that bank size and capitalization are the only variables to positively and significantly affect NIM, while the impaired loans to total loans ratio variable negatively impacted NIM. The second specification models the NIM using only ownership related variables. Our results show that NIM is affected by all four of the ownership variables. Being Big Four or having high government ownership significantly and negatively affects NIM, while being independent or having foreign ownership significantly and positively affects NIM. Finally, in our last specification where we include both financial statement and ownership variables as independent variables, we find similar results. NIM is affected positively and significantly by bank size, bank capitalization, independent ownership and foreign ownership, while it is significantly and negatively 
affected by the impaired loans to total loans ratio, being a Big Four bank or having relatively large government ownership.

\section{SUMMARY AND CONCLUSIONS}

Our study examined the impact of ownership structure on Chinese banks' profitability. We examined the effect of Chinese government ownership, private ownership and foreign ownership on the financial performance measures of Chinese banks. We tested three hypotheses. First, Government ownership is negatively related to Chinese banks' performance. Second, independent ownership in Chinese banks affect positively financial performance. Third, foreign ownership has positive impact on Chinese banks' financial performance. Our results strongly support all three hypotheses. Our findings conclude that relatively high government ownership has a negative impact on the Chinese bank performance measures. Similarly, the presence of higher levels of foreign ownership and private ownership in Chinese leads to relatively higher performance measures.

Our paper adds to the existing banking corporate governance research by shedding light on the importance of ownership structure on Chinese bank performance. Our results indicate the profitability and performance do not have utmost importance in government controlled Chinese banks, in contrast to the positive role of private and foreign ownership. Our paper has some limitations that are noteworthy to mention and which can provide opportunities for future studies. First, we only use ownership related variables and financial measures as variables of study in this paper. It would be interesting to study the real motives behind the Chinese government ownership of Chinese banks by incorporating other measures and variables to study empirically test the drivers of the Chinese government motives. 


\section{REFERENCES}

Alchian, A.A. (1965). Some economics of property rights. II Politico, 30, 816-829.

Altunbas, Y., Evans, L., \& Molyneux, P. (2001). Ownership and efficiency in banking. Journal of Money, Credit and Banking, 33(4), 926-54.

Berger, A.N., De Young, R., Genay, H., \& Udell, G.F. (2000). Globalization of financial institutions: evidence from cross-border banking performance. Brookings-Wharton Papers on Financial Service, 3, 23-158

Bonin, J.P., Hasan, I., \& Wachtel, P. (2005a). Bank performance, efficiency and ownership in transition countries. Journal of Banking and Finance, 29, 31-53.

Bonin, J.P., Hasan, I., \& Wachtel, P. (2005b). Privatization matters: Bank efficiency in transition countries. Journal of Banking and Finance, 29, 2155-2178.

Garcia-Herrero, A., Gavila, S., \& Santabarbara, D. (2009). What Explains the low profitability of Chinese Banks? Working paper No 0910, Banco De Espana.

Hsu, S. (2016). China's Banking Sector as the Foundation of Financial Reform, Asia and the Pacific Policy Studies, 3, 244-248.

Jensen, M. C., \& Meckling, W.H. (1976). Theory of the firm: managerial behaviour, agency costs and ownership structure. Journal of Financial Economics, 3, 305-360.

Jiang, C., Yao, S., \& Zhang, Z. (2009). The Effects of Governance Changes on Bank Efficiency in China: A Stochastic Distance Function Approach. China Economics Review, 20(4), 717-731.

La Porta, R. F., Lopez-de-Silanes, F., \& Shleifer, A. (2002). Government ownership of banks. Journal of Finance, 57, 265-301.

Lin, X., \& Zhang, Y. (2009). Bank ownership reform and bank performance in China. Journal of Banking and Finance, 33(1), 20 - 29.

Kumbhakar, S.C., \& Wang, D. (2005). Economic reforms, efficiency and productivity in Chinese banking. State University of New York - Binghamton working paper.

Micco, A., Panizza, U., \& Yanez, M. (2007). Bank Ownership and Performance. Does Politics Matter? Journal of Banking Finance, 31, 219-241.

Raluca, B. I. (2013). Literature Review Regarding the Determinants of Banking Profitability. Ovidius University Annals, Economic Sciences Series, Ovidius University of Constantza, Faculty of Economic Sciences, 0(1), 1130-1134.

Sapienza, P. (2004), The effects of government ownership on bank lending. Journal of Financial Economics, 72(2), 357-384. https://doi.org/10.1016/j.jfineco.2002.10.002. 